\section{On the Sulphate Metabolism in the Sulphocerebrosides of the Brain}

\author{
Åk Holmgår d \\ Chemistry Department II, Karolinska \\ Institutet, Stockholm, Sweden
}

In connexion with Boström's work on the sulphate exchange in the chondroitin sulphuric acid of cartilage, investigations have been made at our Institute of whether a similar exchange of sulphate takes place in heparin and in the cerebroside sulphuric acid of the central nervous system.

It was shown in a study by Magnusson and Larsson ${ }^{1}$ that radioactive sulphate is incorporated in the heparin of mastocytomas in the dog. This was also found to apply to cerebroside sulphuric acid.

The sulphur uptake in the central nervous system has been studied by Dziewiatkowski ${ }^{2}$ in the rat, using oral doses of sodium sulphide contrining ${ }^{85} \mathrm{~S}$. He recovered $0.02 \%$ of the dose given in the brain. The same experiments have been made in the rabbit, with similar results.

Boström and Odeblad s used the autoradiographic technique to demonstrate the sulphate uptake in the brain; they found the highest concentration in the grey matter.

In order to ascertain whether radioactive sulphate is incorporated in the sulpholipids of the brain, 4 rabbits were each given an intramuscular injection of $3 \mathrm{mC}$ of carrier-free sodium sulphate containing ${ }^{35} \mathrm{~S}$. The animals were killed 108 hours later. The sulpholipid was isolated according to Blix *, but it was not possible to perform the last stage, since the basic material was insufficient. To eliminate inorganic sulphate, the sulpholipid was passed at $42^{\circ} \mathrm{C}$ through an anion exchange column (Dowex 2). The activity was determined in a surface of $1.58 \mathrm{~cm}^{2}$ and a layer of infinite thickness. The results are shown in Table 1.

Table 1.

$\begin{array}{lcc} & \text { Weight } & \text { Counts' } \\ & \mathrm{g} & \mathrm{min} \text {. } \\ \text { Acetone-dried brain } & \mathbf{5 . 0 6} & 110 \\ \text { Protagon } & \mathbf{0 . 7 6 5} & \mathbf{2 2 2} \\ \text { Sulpholipid } & \mathbf{0 . 0 1 0} & \mathbf{9 9 8}\end{array}$

The same experiment was made in the rat, with similar results.
In order to rule out the possibility that the activity was due to contamination by chondroitin sulphuric acid, the following experiment was made. To $1.21 \mathrm{~g}$ of cattle protagon was added $0.91 \mathrm{~g}$ of ${ }^{\mathrm{a}} \mathrm{S}$-labelled chondroitin sulphuric acid, so that an activity of 527 counts/ min. was obtained. The sulpholipid was then isolated from the mixture. It had no radioactivity.

It is concluded that an exchange has taken place between the sulphate group of the brain sulpholipid and the labelled free sulphate.

1. Magnusson, S. and Larsson, B. Acta Chem. Scand. 9 (1955) 534.

2. Dziewiatkowski, D. D. J. Biol. Chem. 161 (1945) 723.

3. Boström, H. and Odeblad E. Acta Psychiatr. et Neurol. Scand. 28 (1953) Fasc. 1.

4. Blix, G. Hoppe-Seylers Z. physiol. Chem. 219 (1933) 82.

\section{Purification and Chemical Prop- erties of Enterokinase \\ Ik uo Yamashina \\ Chemistry Department II, Karolinska \\ Institutet, Stockholm, Sweden}

Enterokinase, an enzyme which accelerates the transformation of trypsinogen to trypsin, was purified as follows.

Duodenal fluid contents of swine was digested by proteolytic enzymes, followed by ammonium sulfate fractionation under $\mathrm{pH}$ con. trol. The crude preparation thus obtained was submitted to the fractionation by organic solvents. Ethanol fractionation at pH 4.5 in the presence of $5 \%$ calcium acetate and acetone fractionation at $\mathrm{pH} 5.5-5.9$ in the presence of zinc were repeatedly applied. Finally, a highly active preparation (2 600 units per $\mathrm{mg}$ ) which is 65 times more active than Kunitz's preparation in 1939 was obtained with the yield of $20 \%$. This preparation is fairly pure, in electrophoresis and ultracentrifugation. The isoelectric point is at around pH 4.0. The analyses showed that it contains a high content of carbohydrate (ca. $30 \%$ ), aminosugar being $13 \%$ (glucosamine $10 \%$ and galactosamine $3 \%$ ) and neutral sugars $15 \%$ (fucose $4 \%$, mannose $3 \%$, and galactose $8 \%$ ) based on chromatographic methods.

The carbohydrate content increased follow. ing the increase of the ectivity during the purification. 